\title{
Tree pruning in the structural approach to vowel reduction and lenition
}

\author{
Karolina Drabikowska \\ John Paul II Catholic University of Lublin, Poland
}

\begin{abstract}
The article scrutinises several vowel reduction and lenition phenomena by employing a model of syntax-like structural representations, i.e. Government Phonology 2.0. In contrast to the standard GP model, whereby lenition and vowel reduction can be viewed as shortening, element suppression or status switching, the structural approach employs the procedure of tree pruning with a heavily limited role of melodic annotation. This paper will take a closer look at node removal with special attention to its trajectory. In particular, two basic directionalities are considered: top-down and bottom-up. The former has been proposed to account for vowel reduction whereby the highest positions are deleted retaining the head and potentially its sister. The acquisition of plosives and fricatives points to the latter trajectory, which disposes of nodes closer to the head. However, the choice of positions that are targeted in weak contexts might be also related to the inherently encoded hierarchy of terminal nodes within the constituents in question.
\end{abstract}

Keywords: vowel reduction, lenition, structure, tree pruning, phonological representation

\section{Introduction}

Models of phonological representation that utilise privative units recognise lenition and vowel reduction as a loss, suppression or deactivation of melodic content in weak prosodic positions. Government Phonology addresses this issue by assigning weak positions less licensing power to sustain melodic primes (Harris 1990, 1994, 2005). In effect, this process becomes defined as shortening of long segments, simplification of complex expressions by suppression of some elements and changing the status of head elements to non-heads (cf. Backley 2011: 50-54, 184194). An innovative approach put forward by Pöchtrager (2006), the so-called GP 2.0, adopts a structural model of phonological representation and considers reduction a structural simplification by means of node removal. In this view, two directions of such tree pruning can be proposed: top-down or bottom-up. This paper aims to establish whether any of these approaches can be favoured by investigating several phenomena occurring in weak positions across languages. The paper is organised as follows: section 2 outlines the tenets of GP 2.0 with special attention to the structural organisation of representations; section 3 presents the process 
of tree pruning in language acquisition, as proposed by Úlfsbjörninn (2008). In section 4, some vowel reduction phenomena are analysed employing GP 2.0 structures with special attention paid to the directionality of tree pruning. Section 5 includes several remarks with regard to lenition.

\section{The structural model of phonological representation - Government Phonology 2.0}

GP 2.0, developed by Pöchtrager (2006), Pöchtrager and Kaye (2010; 2013) and Živanović and Pöchtrager (2010), is a twenty-first-century offshoot of Government Phonology, in that it is a non-derivational model, which makes no distinction between phonological and phonetic representations, and it follows a set of basic principles, including the Minimalist Hypothesis (Kaye 1992: 141), Licensing Principle (Kaye 1990: 306) and Projection Principle (KLV 1990: 221). The divergence from the standard framework is to use tree diagrams borrowed and adapted from the Minimalist Program in syntax (Chomsky 1995). Apart from that, GP 2.0 uses three privative elements as proposed within Element Theory, namely I, U and L, whose phonetic correlates can be defined as follows: ${ }^{1}$

\begin{tabular}{ll}
\hline prime & phonetic correlates \\
\hline I & palatality, "dIp" pattern - low F1 coupled with high spectral peak (convergence of F2 and F3) \\
\hline U & labiality, "rUmp" pattern - low spectral peak (convergence of F1 and F2) \\
\hline L & nasality, VOT lead \\
\hline
\end{tabular}

Beside these primes, phonological information is expressed by means of structural configurations and relationships between nodes. ${ }^{2}$ The elements $h$ (noise) and $?$ (occlusion) are in GP 2.0 replaced by projections. In other words, the representations are composed of more than one position. In effect, fricatives comprise two terminal nodes under a single projection $(2 a-b)$, while plosives have three positions in a double-layered projection $(2 c-d)$. The correlates of $\mathrm{H}$ (VOT lag) are encoded in the licensing relationship between the head $(\mathrm{xO})$ and the highest complement $\left(\mathrm{x}_{1}\right)$, i.e. $\mathrm{m}$-command represented in a form of arrows running along the projection lines $(2 \mathrm{a}, \mathrm{c})$. Licensing in the form of control (the arrow between $\mathrm{x}_{2}$ and $\mathrm{xO}_{3}$ in $2 \mathrm{c}-\mathrm{d}$ ) assures that the terminal node $\mathrm{x}_{2}$ in plosives is sanctioned by the head.

(2) a. [f]

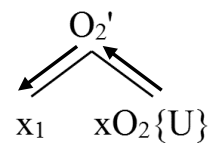

b. $[\mathrm{v}]$

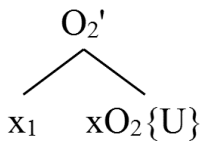

c. $[\mathrm{p}]$

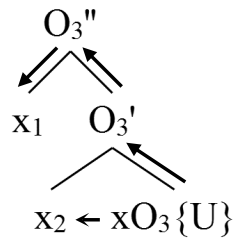

d. [b]

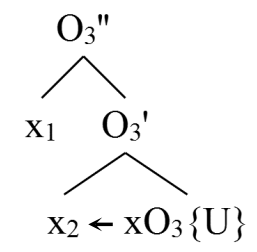

Additionally to voicelessness, m-command assures the length of vowels, hence the representation of a long monophthong with the head $\mathrm{xN}_{1}$ licensing the complement $\mathrm{x}_{2}$, as shown in (3):

1 The descriptions of "dIp" and "rUmp" acoustic patterns come from Harris (1996).

2 For arguments in favour of such a treatment, see Pöchtrager $(2006,2010)$ and Pöchtrager and Kaye $(2010,2013)$. 
(3) $[\mathrm{u}:]$

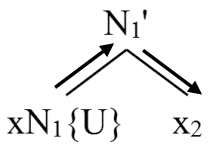

In each of the above representations, one position is assigned the status of the head. It is marked by $\mathrm{O}$ or $\mathrm{N}$, depending on whether the structure in question stands for a consonant or vowel, respectively. Terminal nodes can be annotated with melodic primes I, U or L, which are understood as position properties.

Due to the exceptional behaviour of coronals and non-low vowels (cf. Pöchtrager 2006, Pöchtrager and Kaye 2010), in GP 2.0 the element A is proposed to be replaced by adjunction, i.e. a split node with an additional position, as in (4).

(4) Adjunction
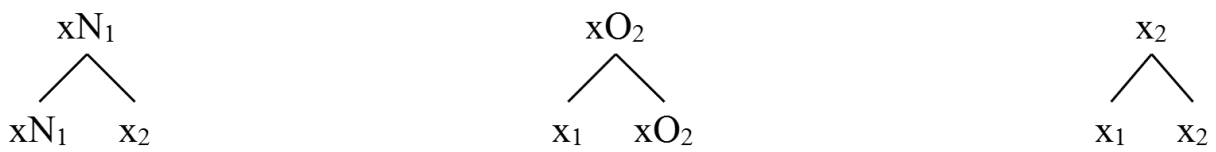

Besides the projecting structures and complex configurations presented above, short vowels and glides are represented within the GP 2.0 model by single positions, namely, nonprojecting heads, as in (5).
(5) a. [I]
b. $[v]$
$\mathrm{xN}\{\mathrm{U}\}$
c. $[\mathrm{j}]$
$\mathrm{xO}\{\mathrm{I}\}$
d. $[\mathrm{w}]$
$\mathrm{xO}\{\mathrm{U}\}$

Any reduction processes that all of the above structures (2-5) are concerned with potentially involve a loss of terminal nodes (x-positions) and/or melodic annotation. In the following sections, I will delve into the previous proposals and investigate whether the pruning of terminal nodes proceeds in any particular fashion and what the role of melody in these processes is. Additionally, I will look into how the distance from the head of the expression affects the position's vulnerability to being deleted and whether licensing (e.g. in a form of m-command) plays any particular role in preventing tree pruning.

\section{Tree pruning in language acquisition}

An interesting argument for the directionality of tree pruning comes from Úlfsbjörninn (2008), who takes into account processes occurring at the early stages of first language acquisition. Looking at data from various empirical studies, it appears that stops are acquired before fricatives. However, in the structural approach, fricatives are structurally simpler (notice that in the standard GP they are melodically simpler as well), therefore the logical path would be for children to acquire and produce fricatives sooner. Yet, the evidence shows that they tend to be dropped or realised as stops, as in the following examples (Bernhardt and Stemberger 1998, as cited in Úlfsbjörninn 2008: 134): 
(6) German one-year-old obstruent production

a. Dropped fricatives

$$
\begin{array}{llll}
{[\text { at }]} & \text { for } & \text { [zat }] & \text { 'satisfied' } \\
{[\text { aka] }} & \text { for } & \text { [vagn }] & \text { 'car' }
\end{array}
$$

b. $\quad$ Fricatives realised as stops

$\begin{array}{llll}\text { [dat }] & \text { for } & \text { [zat }] & \text { 'satisfied' } \\ \text { [gaga] } & \text { for } & {[\text { vagn }]} & \text { 'car' } \\ \text { [nana }] & \text { for } & {[\text { na:za }]} & \text { 'nose' }\end{array}$

Contrary to what the theory predicts, the child does not utter a fricative but a plosive or drops the consonant altogether. Additionally, Úlfsbjörninn's (2008) inquiry into the occurrence of plosives and fricatives in the world's languages reveals that there are no natural languages with fricatives but no plosives. Consequently, plosives have to be regarded as "more primitive" than fricatives and, as more complex structures (two layers), they are constructed first as "'default' onset structures" (Úlfsbjörninn 2008: 134-135). In the process of speech development, fricatives emerge when one of the complements is removed. The tree pruning is argued to dispose of the lowest complement, which, as a result, rules out control in fricatives. What is targeted in language acquisition is the position closest to the constituent head, i.e. its sister complement position $\mathrm{x}_{2}$ as in $(2 \mathrm{~d})$, at the bottom of the structure.

It can be concluded that non-head positions that are within the lowest projections of consonants (sisters of heads) are prone to be pruned. As lenition is considered a mostly diachronic phenomenon creating synchronic patterns (cf. Bauer 1988; Millar and Trask 2015; Scheer and Ségéral 2008), the prediction could be that the same principle - i.e. the bottom-up directionality - applies to vowel reduction and lenition phenomena. In the following sections, I will try to verify whether this prediction is indeed correct.

\section{Vowel reduction}

An instance of vowel reduction that has already been tackled within GP 2.0 is that of vowel neutralisation in unstressed positions in Brazilian Portuguese and Eastern Catalan (see Pöchtrager 2016ab, 2018). The vocalic inventory of Brazilian Portuguese comprises seven vowels in stressed positions $[\mathrm{i}],[\mathrm{e}],[\varepsilon],[\mathrm{a}],[\mathrm{o}],[\mathrm{o}]$ and $[\mathrm{u}]$, with the number diminished to five $[\mathrm{i}],[\mathrm{e}],[\mathrm{a}],[\mathrm{o}]$ and $[\mathrm{u}]$ in pretonic positions and to three $[\mathrm{i}],[\mathrm{a}],[\mathrm{u}]$ in posttonic positions. The vowels that undergo reduction are the mid ones, as the mid-open/mid-close contrast is neutralised to mid-close and high vowels, as in (7).

(7) Brazilian Portuguese (Cristófaro Silva 1992)

\begin{tabular}{lll}
\hline tonic & pretonic & posttonic \\
\hline $\mathrm{i}$ & $\mathrm{i}$ & $\mathrm{i}$ \\
$\mathrm{e}$ & $\mathrm{e}$ & \\
\hline$\varepsilon$ & $\mathrm{a}$ & $\partial$ \\
\hline $\mathrm{a}$ & $\mathrm{o}$ & $\mathrm{u}$ \\
\hline $\mathrm{o}$ & $\mathrm{u}$ & \\
\hline $\mathrm{u}$ & $\mathrm{u}$ & \\
\hline
\end{tabular}


While the standard GP account of the merger of [e] and [i] to [i] is that of the loss of the operator A $($ A. $\underline{I}>\underline{I})$, the merger of $[e]$ and $[\varepsilon]$ to $[e]$ requires a status switch of I from the operator to the head (I.A $>$ I.A). In the former, the output seems weaker since the elemental makeup is depleted. The latter appears to be stronger as the expression becomes headed. Such an interpretation seems inconsistent as not only does it put forward two different phonological operations in order to account for the same phenomenon, but also uses a strengthening mechanism for one of them. Additionally, even if we assume that the representation of $[\varepsilon]$ contains headed A, i.e. (I.A), the motivation for the exchange of status between the elements is questionable and does not reflect any reduction or weakening. Contrary to the inconsistent treatment by the standard model, in GP 2.0 the reduction trajectory is a logical sequence of representations involving a gradual loss of terminal nodes with the subsequent removal of upmost projections, as in (8).

(8) Reduction trajectory in Brazilian Portuguese (adapted from Pöchtrager 2018: 57) 3

$[\varepsilon]$

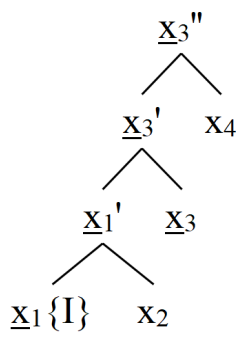

[e]

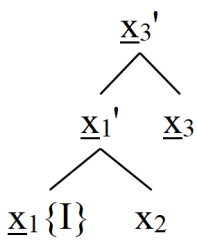

[i]

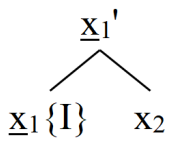

As can be noticed in (8), the positions targeted in the vowel reduction are the ones situated further from the head. In pretonic context, it is the position $\mathrm{x}_{4}$ that becomes deleted and the vowel is therefore reduced to a double-layered projection, i.e. [e]. In posttonic context, two positions, namely all projections of $\mathrm{x}_{3}$, including position $\mathrm{x}_{4}$, are removed, yielding the high vowel [i]. The annotation of $I$ to $x_{1}$ is not affected by the process at all. The stipulation here is that melodic annotation is allowed without any form of additional support exclusively in head positions. Such a stance is sound on both theoretical and empirical grounds, as it constitutes a necessary restriction and, as shown by Drabikowska (2019), annotation to non-head positions is sustained under strict conditions, i.e. it must be supplied with some form of licensing, and can have phonetic consequences (cf. Živanović and Pöchtrager 2010).

As melodic annotation of heads is not further restricted, an alternative solution, i.e., to annotate $\mathrm{x}_{3}$ with the I prime, allows an account of Eastern Catalan lenition, which proceeds from $[\varepsilon]$ and $[e]$ directly to $[ə]$, as in (9).

3 Following Pöchtrager's (2018) convention, in (8) and (9), the heads are underlined. The marking of adjunction and assigning headedness here is more vague than in the representations of consonants above or vowels below, but for the sake of the present considerations, it is sufficient to assume that open vowels have more structure. In these representations, I decided to place some of the heads on the right (contrary to established convention for vocalic constituents), since the alternation does not seem to affect the phonetic interpretation of the structures and allows me to notate positions with consecutive numbers, which facilitates the references in the following discussion. For some arguments that a change in positioning (left vs. right) might indeed affect phonetic interpretation in some languages, see Drabikowska (2019). 
(9) Reduction trajectory in Eastern Catalan (adapted from Pöchtrager 2018: 57)

$[\varepsilon]$

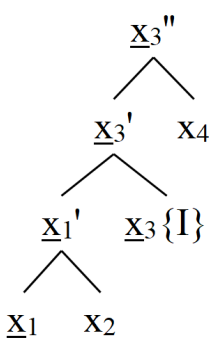

[e]

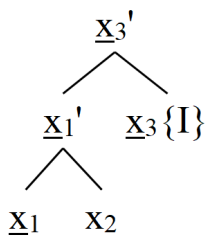

[ə]

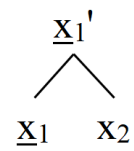

In (9), the reduction proceeds top-down as in Brazilian Portuguese, with the exception of the side effect in the form of melody loss since it is a property of position $\mathrm{x}_{3} .{ }^{4}$ In both languages the reduction proceeds downwards, that is, the most vulnerable positions are the top ones. In other words, the closer the complement is to the head, the more likely it is to be preserved in the structure.

A slightly different picture emerges in some of the Northern varieties of Italian, namely, the ones found in the area of Martignana di Po and San Benedetto Po in Lombardia. These varieties demonstrate the neutralisation of vowels in pretonic positions. While tonic positions allow fifteen vowels [i:, y:, e:, u:, $\varnothing(:), \varepsilon(:), a(:), \curvearrowright(:), \mathrm{I}, \mathrm{v}, \mathrm{e}$ ] in Martignana di Po and fourteen [i:, y:, e:, u:, $\varnothing(:), \varepsilon(:), a(:), \jmath(:), v, ~ ə]$ in San Benedetto Po, pretonic positions allow only four [i, $y, a$, u] in both varieties (see Savoia 2015: 128-130, 277-278). The processes involved testify not only to the reduction of tree structure but also to the role of $\mathrm{m}$-command.

The neutralisation of mid front vowels closely resembles the process occurring in Brazilian Portuguese in that they are reduced to [i] in pretonic positions. Moreover, the result of reduction does not differ when long vowels are concerned. Namely, in both varieties long and short mid vowels are reduced to [i], as in [a 'be:vi] 'drink.1sg.pres' vs. [a bi'vom] 'drink.1pl.pres', [a 'epeti] 'wait.1sg.pres' vs. [a cpi'tom] 'wait.1pl.pres'. This reduction can be represented as follows:

(10) $[\varepsilon]$

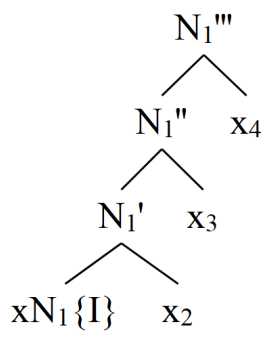

[e:]

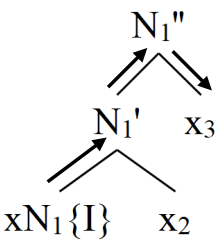

[i]

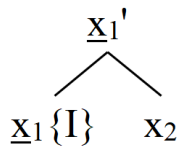

The procedure presented in (10) shows an important aspect of tree pruning. In particular, the $\mathrm{m}$-command that holds between the head $\mathrm{xN}_{1}$ and the complement $\mathrm{x} 3$ in the representation of the long vowel [e:] does not prevent tree pruning, since the resulting vowel is short. The reduction, which proceeds from the top, prunes upmost nodes yielding a short vowel represented by a single projection with the head no longer $\mathrm{m}$-commanding its complement.

\footnotetext{
4 Apart from accounting for reduction, different placement of the element I in Brazilian Portuguese and Eastern Catalan explains different outcomes of palatalisation in those languages (see Pöchtrager 2018: 58-60).
} 
The element placement, in turn, assures its quality as the high front vowel [i]. As it is the head that is annotated with a melody (the element $\mathrm{I}$ ), the prime is not affected by the reduction and is retained in the structure. ${ }^{5}$ Additionally, the difference in the number of nodes representing these vowels (four vs. three) and the irrelevance of m-command in this context is further supported by the fact that in some cases the vowel [e:] is deleted altogether, as in [a 'le:vi] 'lift.1sg.pres' vs. [a l'va] 'lift.past.pc' in Martignana di Po and [a 'be:vi] 'drink.1sg.pres' vs. [a v'bøm] 'drink.1pl.pres' in San Benedetto Po (cf. Savoia 2015: 277-278).

\section{Lenition}

As vowels in weak positions are characterised by a smaller number of projection layers than vowels in stressed positions, what seems primarily indicative of strength in GP 2.0 is the complexity of structures. The same applies to consonants. A clear example of the structurallyencoded strength is a set of representations of consonants in English with reference to strength scale as can be inferred from the discussion presented in Cyran (2010: 13-19). Here the stronger segments have greater distributional freedom. They can occur in the prosodic positions that are endowed with greater licensing potential and as such can be governors, hence the following scale:

(11) Strength scale in English

\begin{tabular}{llll}
\hline voiceless stop $\quad$ voiced stop / voiceless fricative $\quad$ voiced fricative & glide & $\varnothing$
\end{tabular}

As proposed by Harris (1990), strength is correlated with the number of elements. Therefore, the above scale can be exemplified by the following labial representatives (12):

(12) GP representations

\begin{tabular}{|c|c|c|c|c|}
\hline a. [p] & b. $[\mathrm{b}] /$ & {$[\mathrm{f}]$} & c. $[\mathrm{v}]$ & d. $[\mathrm{w}]$ \\
\hline $\mathrm{O}$ & $\mathrm{O}$ & $\mathrm{O}$ & $\mathrm{O}$ & $\mathrm{O}$ \\
\hline | & | & | & | & | \\
\hline $\mathrm{x}$ & $\mathrm{x}$ & $\mathrm{x}$ & $\mathrm{x}$ & $\mathrm{x}$ \\
\hline | & | & | & | & | \\
\hline U & U & U & U & U \\
\hline $\mathrm{h}$ & $\mathrm{h}$ & $\mathrm{h}$ & $\mathrm{h}$ & \\
\hline$?$ & $?$ & $\mathrm{H}$ & & \\
\hline
\end{tabular}

These representations demonstrate how the decreasing number of elements - from four elements for the voiceless plosive [p], through three for the voiced plosive [b] and the voiceless fricative $[\mathrm{f}]$ and two for the voiced fricative $[\mathrm{v}]$ to one element for the glide $[\mathrm{w}]$ - is reflective of

\footnotetext{
5 Interestingly in Martignana and San Benedetto, [ $\varepsilon$ ], when followed by [r] is neutralised to [a], as in [' pe:rdi] 'lose.1SG.PRES' vs. [par'dum] 'lose.1PL.PRES' (Savoia 2015: 2 77). It might be stipulated that here the melody loss is connected with the presence of adjunction in two adjacent constituents and the resulting relationship between them in a closed syllable. This issue, however, is beyond the scope of this paper.
} 
the decline in segmental strength. Let us now compare how the scale maps onto the GP 2.0 structures.

(13) GP 2.0 representations
a. $[\mathrm{p}]$
b. [b]

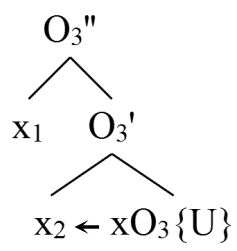
c. $[\mathrm{v}]$
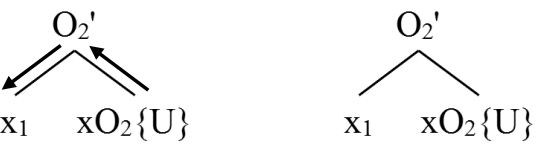
d. $[\mathrm{w}]$ $\mathrm{xO}\{\mathrm{U}\}$

As can be noticed in (13), the decrease of strength is encoded in the structural complexity. However, what is significant is not only the number of nodes or layers but also the licensing relations between the head and its complements. Counting only projections, voiced and voiceless plosives (13a) and (13b) are equally complex with three terminal nodes. What sets them apart is the $\mathrm{m}$-command between the head $\mathrm{xO}_{3}$ and the complement $\mathrm{x}_{1}$ in (13a), which stands for the voicelessness of [p]. Similarly, the voiced plosive and the voiceless fricative (13b) are of comparable strength (as also supported by Escure 1977 and Ewen and van der Hulst 2001, where they are considered alternative routes of lenition trajectories across the world's languages). It can be concluded that m-command also adds to the complexity and its contribution is roughly equivalent to one layer of projection. The voiced fricative (13c) lacks $\mathrm{m}$-command and is considered weaker on the scale, but it is stronger than the glide [w] (13d), which is a non-projecting head. What seems striking here is that the licensing in the form of $\mathrm{m}$ command might have a more prominent role in consonantal representations. Let us consider the picture that is revealed when we consider lenition of $[t]$ in some English varieties, i.e. glottalisation foot-internally and word-finally (14a), most notably occurring in England and Scotland, and tapping in foot internal and word-final positions before a vowel, a consonant or a pause (14b), which is characteristic of North America, Australia, Ireland and parts of England, ${ }^{6}$ as in the following examples (cf. Harris 1994; Bloch-Rozmej 2011):

(14) Lenition of [t] (Harris 1994: 121)

a. glottalisation

$\begin{array}{ll}b i[\mathrm{t}] & >b i[\mathrm{~T}] \\ p i[\mathrm{t}] y & >p i[\mathrm{?}] y \\ w a[\mathrm{t}] e r & >w a[\mathrm{~T}] \text { er } \\ \text { tapping } & \\ f i[\mathrm{t}] & >f i[\mathrm{r}] \text { us / fi }[\mathrm{r}] \mathrm{me} \\ p i[\mathrm{t}] y & >p i[\mathrm{r}] y \\ w a[\mathrm{t}] e r & >w a[\mathrm{r}] e r\end{array}$

Lenition is by no means restricted to English and has been extensively discussed for years. Various accounts and analyses have been provided concerning numerous languages, including Romance, Celtic, Germanic and Slavic families to name a few, and using many theoretical frameworks, for example, Martinet (1952), Oftedal (1985), McCone (1996), Bloch-Rozmej (1998), Jaskula (2006), Giannelli and Savoia (1979), a collection of papers in de Carvalho, Scheer and Ségéral (2008) and numerous references therein. Whether optional or obligatory, the expectation is that the phenomena are inherently the same with respect to the processes affecting structural representations. 
The standard Government Phonology approach to both these types is to consider them a loss or suppression of elements. Tapping is thus the loss of the noise element $h$, while glottalisation involves delinking of $\mathrm{A}$ and $\mathrm{h}$. In both processes, the laryngeal prime $\mathrm{H}$ is suppressed as well, as below in (15).

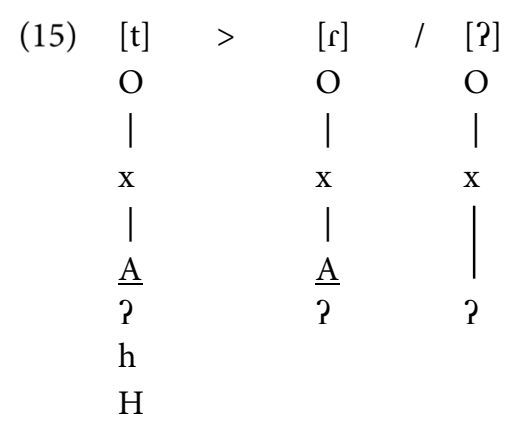

Interestingly, in Ireland and Meyerside area of England, lenition might result in spirantisation of [ $\mathrm{t}$ ] to [s] in intervocalic and word-final positions (16a) and might proceed even further to debuccalisation to $[\mathrm{h}]$ in weakly stressed function words (16b).

(16) Lenition of [t] (Harris 1994: 121)

a. spiratisation

$g e[\mathrm{t}]>g e[\mathrm{~s}]$

$l e[\mathrm{t}] e r>l e[\mathrm{~s}] e r$

b. debuccalisation

$a[\mathrm{t}]>a[\mathrm{~h}]$

$n o[\mathrm{t}]>n o[\mathrm{~h}]$

The standard representation of the trajectory is as follows:

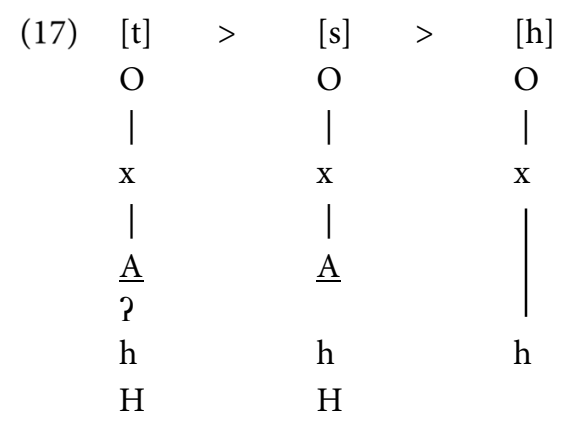

The standard GP treatment of these reduction phenomena seems appealing in that there is a straightforward correspondence between the number of primes and the licensing potential of positions. Nevertheless, the approach is not without a flaw, as a reservation concerning the targeting of primes can be raised against the above treatment. In particular, the reduction processes are not consistent in the way they target the primes with relation to their status. While tapping disposes of $\mathrm{h}$ and $\mathrm{H}$ - both non-head elements - and preserves the head A, glottalisation reduces the melody to a single non-head prime, i.e. ?. Moreover, the targeting of non-head primes in various dialects has to be attributed to chance, since no explanation can be provided as to why the end product in one dialect is a single non-head ?, while it is $h$ in another, given that both primes are of equal status. In other words, from a theoretical standpoint, there is no 
means of differentiating the licensing potential of positions in relation to their ability to sustain two different primes of the same status.

With the structural representations of GP 2.0, the matter is still complex but an explanation of why specific positions are targeted is less coincidental. Consider the following GP 2.0 structure for $[\mathrm{t}]$.

(18) $\quad[\mathrm{t}]$

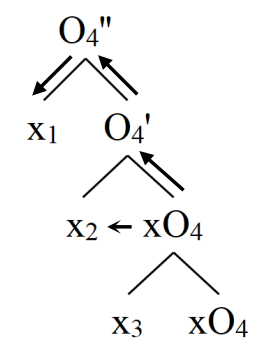

The prediction for lenition is three-fold. It may proceed from the top down eliminating the top-most position $\mathrm{x}_{1}$ alone or together with $\mathrm{x}_{2}$. Conversely, it might target the lowest positions first, i.e., beginning with $\mathrm{x}_{3}$ within the adjunction. Depending on the dialect, different approaches might be employed. The three possible trajectories with nodes being progressively eliminated (marked in grey) are presented below.

(19) Top-down trajectory

\begin{tabular}{|c|c|c|c|}
\hline & Step 1 & Step 2 & Step 3 \\
\hline $\begin{array}{l}\text { Types of } \\
\text { structure }\end{array}$ & $\begin{array}{l}\text { a single-layered projection } \\
\text { (adjunction) }\end{array}$ & a non-projecting adjunction & $\begin{array}{l}\text { a non-projecting head } \\
\text { (no adjunction) }\end{array}$ \\
\hline $\begin{array}{l}\text { Possible } \\
\text { realisations }\end{array}$ & $\begin{array}{l}\text { an unaspirated coronal } \\
\text { fricative }\end{array}$ & a coronal tap & {$[\mathrm{h}]$} \\
\hline $\begin{array}{l}\text { Targetted } \\
\text { positions } \\
\text { visible }\end{array}$ & $\overbrace{\mathrm{xO}_{4}}^{\mathrm{O}_{4}^{\prime \prime}}$ & $\overbrace{\mathrm{x}_{\mathrm{xO}_{4}}^{\mathrm{O}_{4}^{\prime}}}^{\mathrm{O}_{4}^{\prime \prime}}$ & $\overbrace{\mathrm{x}_{3}}^{\mathrm{O}_{4}^{\prime \prime \prime}}$ \\
\hline $\begin{array}{l}\text { Resulting } \\
\text { structures }\end{array}$ & $\overbrace{\mathrm{xO}_{3}}^{\mathrm{O}_{3}^{\prime \prime}}$ & $\overbrace{\mathrm{x}_{1}}^{\mathrm{xO}_{2}}$ & $\mathrm{xO}_{4}$ \\
\hline
\end{tabular}

The trajectory in (19) is fairly simple in that the truncation of $\mathrm{x}_{1}$ must eliminate the $\mathrm{m}$-command between $\mathrm{xO}_{4}$ and $\mathrm{x}_{1}$ in its first step. Step 2 potentially takes us to the tap [ $\mathrm{r}$, which is represented by a non-projecting adjunction. The final step reduces the adjunction to a nonprojecting head. 
The first step in the bottom-up trajectory (as in 20) is to eliminate adjunction, which would result in the reduction of $[t]$ to a plosive unspecified for place. ${ }^{7}$ Nevertheless, the potential of the head being diminished in weak contexts, further steps might produce either a fricative or a glottal stop.

Bottom-up trajectory

\begin{tabular}{|c|c|c|c|c|}
\hline & Step 1 & Step 2a & Step 2b & Step 3 \\
\hline $\begin{array}{l}\text { Types of } \\
\text { structure }\end{array}$ & $\begin{array}{l}\text { a double-layered } \\
\text { projection } \\
\text { (no adjunction) }\end{array}$ & $\begin{array}{l}\text { a single-layered } \\
\text { projection } \\
\text { (no adjunction) } \\
\end{array}$ & $\begin{array}{l}\text { A double-layered } \\
\text { projection (no adjunction, } \\
\text { no m-command) }\end{array}$ & $\begin{array}{l}\text { a non-projecting } \\
\text { head } \\
\text { (no adjunction) }\end{array}$ \\
\hline $\begin{array}{l}\text { Possible } \\
\text { realisations }\end{array}$ & an aspirated plosive & an aspirated fricative & [?] & {$[\mathrm{h}]$} \\
\hline $\begin{array}{l}\text { Targetted } \\
\text { positions } \\
\text { visible }\end{array}$ & $\mathrm{X}_{\mathrm{x}_{3}}^{\mathrm{O}_{4} \mathrm{xO}_{4}}$ & $\mathrm{X}_{\mathrm{x}_{1}}^{\mathrm{O}_{4}^{\prime \prime}}$ & 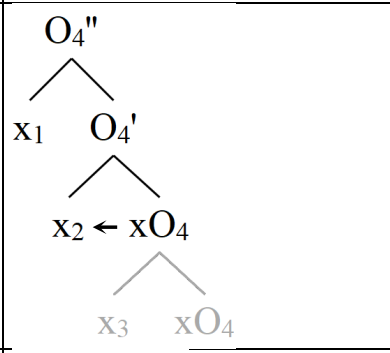 & $\overbrace{\mathrm{x}_{3}}^{\mathrm{O}_{\mathrm{xO}_{4}^{\prime}}^{\mathrm{O}_{4}^{\prime \prime}}}$ \\
\hline $\begin{array}{l}\text { Resulting } \\
\text { structures }\end{array}$ & : & $\mathrm{x}_{\mathrm{xO}_{2}}^{\mathrm{O}_{2}^{\prime}}$ & $\overbrace{\mathrm{x}_{2} \leftarrow \mathrm{xO}_{3}}^{\mathrm{O}_{3}^{\prime \prime}}$ & $\mathrm{xO}_{1}$ \\
\hline
\end{tabular}

None of these two trajectories, however, allow us to ensure a principled account of the reduction of $[\mathrm{t}$ ] to $[\mathrm{s}]$ (and eventually to $[\mathrm{h}]$ ), since either $\mathrm{m}$-command or adjunction is disposed of in the first step. In fact, both of them would have to be retained in order for the process to be accounted for. At a closer inspection at the status of the positions and the strength of different forms of licensing in the phonological structures further explored in Drabikowska (2019), the strongest position in every projection is its head and the greater the distance from the head the weaker the position becomes. However, the employed types of licensing are not of equal strength and prevent positions from being affected by various processes to different degrees. As argued by Pöchtrager (2006: 250), adjunction can be a source of strong licensing (the so-called A-command) that holds between two onset projections that form a cluster. It allows certain positions to be sanctioned, although they are not licensed directly by the head. In other words, adjunction is more powerful with respect to its licensing capabilities. Thus, we can predict that the position $\mathrm{x}_{3}$, i.e. the position dominated by the head-type node in (18), is the least susceptible. When $\mathrm{m}$-command is compared to control, the former is stronger, making position $\mathrm{x}_{1}$ the third strongest. The most vulnerable position in the structure in (18) is $\mathrm{x}_{2}$, as it is sanctioned by the weakest form of licensing (control). Therefore, lenition might also target the positions in the

7 The resulting plosive could be velar, but there is no consensus whether velar consonants in English should be marked by the presence of $U$ in their representations. Backley and Nasukawa (2009) and Backley $(2011,2017)$ argue for a non-head $U$ in velars. 
order from the weakest to the strongest. Based on strength, the following trajectory can be derived:

(21) Strength trajectory (the weakest positions eliminated first, the strongest last)

\begin{tabular}{|c|c|c|c|}
\hline & Step 1 & Step 2 & Step 3 \\
\hline $\begin{array}{l}\text { Types of } \\
\text { structure }\end{array}$ & $\begin{array}{l}\text { a single-layered projection } \\
\text { (adjunction) }\end{array}$ & a non-projecting adjunction & $\begin{array}{l}\text { a non-projecting head } \\
\text { (no adjunction) }\end{array}$ \\
\hline $\begin{array}{l}\text { Possible } \\
\text { realisations }\end{array}$ & an aspirated coronal fricative & a coronal tap & {$[\mathrm{h}]$} \\
\hline $\begin{array}{l}\text { Targetted } \\
\text { positions } \\
\text { visible }\end{array}$ & 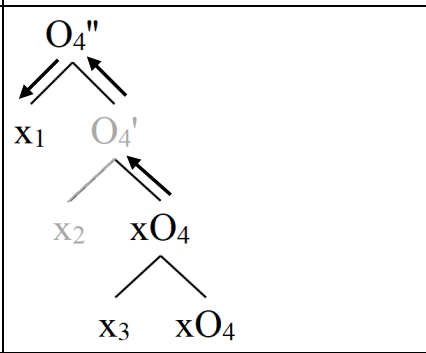 & $\overbrace{\mathrm{x}_{1}^{\mathrm{O}_{2}}}^{\mathrm{O}_{4}^{\prime \prime}}$ & $\overbrace{\mathrm{x}_{3}}^{\mathrm{O}_{\mathrm{xO}_{4}}^{\mathrm{O}_{4}^{\prime \prime}}}$ \\
\hline $\begin{array}{l}\text { Resulting } \\
\text { structures }\end{array}$ & $\overbrace{\mathrm{xO}_{3}}^{\mathrm{O}_{\mathrm{x}_{2}^{\prime}}}$ & $\overbrace{\mathrm{x}_{1}}^{\mathrm{xO}_{2}}$ & $\mathrm{xO}_{1}$ \\
\hline
\end{tabular}

The projections in (21) are trimmed from the bottom as in (19), but due to strength of adjunction the position $\mathrm{x}_{3}$ is spared and retained in the first step yielding an adjunction projecting once and $\mathrm{m}$-commanding the complement under the maximal projection, which is exactly what the spirantisation is, as in (17). Debuccalisation to [h] is the result of two further steps eliminating all of the branches. Taking another look at the data from language acquisition presented by Úlfsbjörninn (2008) and the example where [z] is realised as [n], it might be argued that it is not the lowest position within adjunction that is targeted first but the weakest one the complement controlled by the head. This further confirms that the strength trajectory might be one of the viable options.

Despite its complexity, the advantage of this approach over the standard GP model is that the varying status of positions is inherently encoded in the representations, while elements are equal by principle with no exceptions. They are position properties and their preservation or loss is dependent solely on whether their host position is targeted by lenition. Different dialects may employ different trajectories, but all of them can be defended also on theoretical grounds since the structural and strength hierarchies of positions are inherently encoded in the model.

\section{Conclusions}

The aim of the paper was to explore the process of tree pruning in the structural approach to phonological representations. In particular, some vowel reduction and consonant lenition procedures were looked into. A closer inspection of these phenomena revealed that the hierarchical structure characteristic of the GP 2.0 representations allows a more principled account. The data from language acquisition and consonant reduction show that top-down and 
bottom-up directions might not be the prevalent ones. What seems to play a more significant role is the strength trajectory in which the weakest position is truncated first. Vowel reduction, on the other hand, appears to favour top-down trajectory, which is also connected with the hierarchical organisation of vocalic constituents whereby the positions further from the head are weaker and hence prone to deletion. The role of $\mathrm{m}$-command is not fully uniform across the processes and, as it seems to perform different functions in vocalic and consonantal constituents, its role requires further examination. Future studies could also reveal how common the bottom-up trajectory potentially is across languages.

\section{References}

Anderson, J. M. 1996. The representation of vowel reduction: Non-specification and reduction in Old English and Bulgarian. Studia Linguistica 50: 91-105.

Backley, P. 2011. An introduction to Element Theory. Edinburgh: Edinburgh University Press.

Backley, P. 2017. Headedness in Element Theory: The case for multiple heads. Glossa: A journal of general linguistics 2(1)/89: 1-17. DOI: https://doi.org/10.5334/gjgl.463.

Backley, P., and K. Nasukawa. 2009. Representing labials and velars: A single 'dark' element. Phonological Studies 12: 3-10.

Bauer, L. 1988. What is lenition? Linguistics 24: 381-392.

Bernhardt, B. H., and J. P. Stemberger. 1998. Handbook of phonological development from the perspective of constraint-based non-linear phonology. San Diego: San Diego University Press.

Bloch-Rozmej, A. 1998. Element interactions in phonology. A study in Connemara Irish. Lublin: Redakcja Wydawnictw KUL.

Bloch-Rozmej, A. 2011. Noise as a phonological element: On the representation of plosives and affricates. In: M. Pawlak and J. Bielak (eds.), New perspectives in language, discourse and translation studies. Second language learning and teaching, 13-23. Berlin/Heidelberg: Springer-Verlag.

Chomsky, N. 1995. The Minimalist Program. Cambridge, MA: MIT Press.

Cyran, E. 2010. Complexity scales and licensing in phonology. Berlin/New York: De Gruyter Mouton.

Cristófaro Silva, T. 1992. Nuclear phenomena in Brazilian Portuguese. Ph.D. diss., University of London.

de Carvalho, J. B., Scheer T., and P. Ségéral (eds.) 2008. Lenition and fortition. Berlin: Mouton de Gruyter.

Drabikowska, K. 2019. Substance and function of phonological primes in the Government Phonology tradition. Lublin: Wydawnictwo KUL.

Escure, G. 1977. Hierarchies and phonological weakening. Lingua 43: 55-64.

Ewen, C., and H. van der Hulst. 2001. The phonological structure of words: An introduction. Cambridge: Cambridge University Press.

Giannelli, L., and L. Savoia. 1979. Indebolimento consonantico in Toscana. Revista italiana di diallettologia 2: 2358.

Harris, J. 1990. Segmental complexity and phonological government. Phonology 7: 255-300.

Harris, J. 1994. English sound structure. Oxford: Blackwell.

Harris, J. 1996. Phonological output is redundancy-free and fully interpretable. In J. Durand and B. Laks (eds.), Current trends in phonology. Models and Methods, 305-332. Salford, Manchester: European Studies Research Institute, University of Salford.

Harris, J. 2005. Vowel reduction as information loss. In P. Carr, J. Durand and C. J. Ewen (eds.), Headhood, elements, specification and contrastivity, 119-132. Amsterdam: John Benjamins Publishing.

Jaskuła, K. 2006. Ancient sound changes and Old Irish phonology. Lublin: Wydawnictwo KUL.

Kaye, J. 1990. 'Coda' licensing. Phonology 7: 301-330.

Kaye, J. 1992. On the interaction of theories of Lexical Phonology and theories of phonological phenomena. In W. U. Dressler, H. C. Luschützky, O. E. Pfeiffer and J. Rennison (eds.), Phonologica 1988. Proceedings of the $6^{\text {th }}$ International Phonology Meeting, 141-155. Cambridge: Cambridge University Press. 
Kaye, J., Lowenstamm J., and J.-R. Vergnaud. 1990. Constituent structure and government in phonology. Phonology 7: 193-231.

Martinet, A. 1952. Celtic lenition and Western Romance consonants. Language 28: 192-217.

McCone, K. 1996. Towards a relative chronology of ancient and mediaeval Celtic sound change. Maynooth: St. Patrick's College.

Millar, R. M., and L. Trask. 2015. Trask's historical linguistics. London and New York: Routledge.

Oftedal, M. 1985. Lenition in Celtic and in Insular Spanish. Oslo: Universitetsforlaget.

Pöchtrager, M. 2006. The structure of length. Ph.D. diss., University of Vienna.

Pöchtrager, M. 2010. The structure of A. Paper presented at the 33rd GLOW Colloquium, 13-16 April. Wrocław, Poland.

Pöchtrager, M. 2016a. It's all about size. In P. Szigetvári (ed.), 47 snippets to Mark Adam Nadasdy's $70^{\text {th }}$ birthday. Retrieved from http://seas3.elte.hu/nadasdy70/pochtrager.html.

Pöchtrager, M. 2016b. A structural approach to vowel reduction. Paper presented at Israel Association for Theoretical Linguistics: $32^{\text {nd }}$ Annual Meeting. 25-26 October. Jerusalem.

Pöchtrager, M. 2018. Sawing off the branch you are sitting on. Acta Linguistica Academica 65: 47-68.

Pöchtrager, M., and J. Kaye. 2010. Dial A for adjunction. Paper presented at the Old World Conference in Phonology 7: 28-30 January. Nice.

Pöchtrager, M., and J. Kaye. 2013. GP 2.0. SOAS Working Papers in Linguistics 16: 51-64.

Savoia, L. M. 2015. I dialetti italiani. Sistemi e processi fonologici nelle varietà di area italiana e romancia. Pisa: Pacini Editore.

Scheer, T., and P. Ségéral. 2008. Positional factors in lenition and fortition. In J. B. de Carvalho, T. Scheer and P. Ségéral (eds.) Lenition and fortition, 131-172. Berlin: Mouton de Gruyter.

Úlfsbjörninn, S. 2008. The formal dynamism of categories: Stops vs. fricatives, primitivity vs. simplicity. Poznań Studies in Contemporary Linguistics 44: 121-146.

Živanović, S., and M. Pöchtrager. 2010. GP 2.0 and Putonghua too. Acta Linguistica Hungarica 57: 357-380. 